\title{
Financial Transactions Flow Chart of Fish Marketing at Fish Landing Center (PPI) Lhok Pawoh
}

\author{
Asbahrul Amri, ${ }^{\mathrm{a}, 1^{*}}$, Hardianto Zainal ${ }^{\mathrm{b}, 2}$, Meraty Ramadhini ${ }^{\mathrm{a}, 3}$, \\ Safrijal ${ }^{\mathrm{c}, 4}$, Fahri Maulana ${ }^{\mathrm{c}, 5}$, Muhammad Firdaus ${ }^{\mathrm{c}, 6,}$, \\ ${ }^{a}$ Teknik Industri, Politeknik Aceh Selatan, Tapaktuan, 23711, Indonesia \\ ${ }^{b}$ Teknik Informatka, Politeknik Aceh Selatan, Tapaktuan, 23711, Indonesia \\ ${ }^{c}$ Mahasiswa Teknik Industri, Politeknik Aceh Selatan, Kabeupaten Aceh Selatan, 23711, Indonesia \\ 1asbahrul.alr@gmail.com*,2hardiantozainal@gmail.com, ${ }^{3}$ meraty.ramadhini@yahoo.com, ${ }^{4}$ safrijal3681@gmail.com \\ 5firdausmuhammad828@gmail.com,6fahri.fahri0203@gmail.com
}

ARTICLE INFO

Article history:

Accepted

Kata Kunci:

Financial Transaction Flowchart

Fish Marketing

Market Operator

PPI

ABSTRACT

The fisheries and marine sector is one of the significant sectors in Aceh Province where more than 55\% population of Aceh depend on this sector. Based on the results found in 2014 data collection, fisheries production by South Aceh fishermen reached 20,370.06 tons / year which was marketed inside and outside South Aceh. The problem to be examined in this study is to determine the flow chart of financial transactions in the marketing of fish at the Fish Landing Center level as part of efforts to determine the quality and safety of the catch. This research is designed to answer how the financial transaction process and payment process between market operators. The type of data used in this study is in the form of primary data and secondary data. Qualitative analysis is carried out descriptively which aims to find out deeply about financial transactions at the Lhok Pawoh Fish Landing Center. The results of this study indicate that the type of transaction used at the Fish Landing Center uses external transactions with the payment method divided into two types, namely cash payments and non-cash payments. Most of financial transaction process carried out by market operators at PPI Lhok Pawoh is using the non-cash payment method, except for Muge motor which originating from outside of Lhok Pawoh Village, Muge lapak and consumers who buy fish directly to PPI. In addition, It is also found that only $25 \%$ of Muge motor make cash payments.

Copyright (C) 2020 Politeknik Aceh Selatan. All rights reserved.

\section{Background of Research}

The fisheries and marine sector is one of the significant sectors in Aceh Province where more than 55\% population of Aceh depend on this sector both directly and indirectly [1]. Since 2006, after the tsunami, Aceh's fish production charts began to increase from 126,400 tons of fish produced in 2006 to 159,500 tons in 2014 [2]. The sizable fish production was also followed by the high power consumption of Acehnese fish that exceeded national fish consumption. Aceh fish consumption is at $45.83 \mathrm{~kg}$ / cap / year while national fish consumption is $38.14 \mathrm{~kg} / \mathrm{cap}$ / year. Based on the results of 2014 data collection, the fish produced by Aceh Selatan fishermen reached 20,370.06 tons / year. Where $40 \%$ or 8 tons are sent to North Sumatra and then exported to foreign countries. As many as $3 \%$ of them are processed fish by fishermen. While the rest of it is the local consumption of the people of South Aceh and neighboring regencies such as Subulussalam and Southwest Aceh [3]. Such great potential as mentioned above is not accompanied by an understanding of how the market mechanism is operated. Therefore, knowing the marketing system, especially financial transactions, is very important as a basis for determining the level of security and quality of fish distributed to consumers. 


\section{Theoritical Review}

\section{A. Market}

A simple market can be interpreted as a place of exchange of goods and services [4]. According to Staton W.J is a group of people who have a desire to be satisfied, money to spend, and a willingness to spend [5]. From the above understanding it can be concluded that each market has facilities for the occurrence of transactions, the existence of sellers and buyers who are interested and agree to exchange goods or services.

\section{B. Marketing}

Marketing is a social and managerial process whereby individuals and groups get what they need and want by creating and exchanging products and values with other parties [6]. In other words marketing is a process or activity that delivers products from producers to consumers so that it becomes a bridge between producers and consumers [7].

\section{Market Operator}

Market operator means a person who manages and the person who operates a regulated market business and may be a regulated market itself. Every market operator must at all times have a fairly good reputation, have sufficient knowledge, skills and experience to carry out their functions in the market operator, must act with honesty, integrity and independence of mind [8].

\section{Financial Transaction}

Transaction is an activity carried out by a person which causes changes to the assets or finances owned by either increasing or decreasing. For example, selling property, buying goods, paying debts, and paying various kinds of costs to make ends meet. In a transaction there is a transaction administration. What is meant by administration here is an activity to record changes in a person's finances or organizations carried out carefully and to use certain methods [9].

\section{E. Payment Sistem}

Payment system is a system that includes a set of rules, institutions and mechanisms used to carry out the transfer of funds to meet an obligation arising from an economic activity. Payment instruments are arguably developing very rapidly and advanced. If we look back at the beginning of the known means of payment, the barter system between goods traded is a custom in the premodern era. In its development, began to be known certain units that have a payment value better known as money. Until now, money is still one of the main payment instruments in force in the community. Furthermore, payment instruments continue to evolve from cash-based (non-cash) to non-cash payment instruments such as paper-based payment instruments, for example, checks and crossed checks. Also known as paperless payment instruments such as electronic funds transfers and payment instruments using cards (based card) [10].

\section{F. Flow Chart}

Flow Chart is a logical system-oriented description of the data flow that defines the mapping of information flow into the structure of the program used to facilitate users to better understand the system to be developed [11]. The function of flow diagrams is to illustrate, simplify a series of processes so that they are easily understood and easily seen based on the sequence of steps of a process. The symbols commonly used in flow charts can be seen in table 1 .

Table 1 . The symbols commonly used in flow charts

\begin{tabular}{clll}
\hline No & Mark & \multicolumn{1}{c}{ Name } & \multicolumn{1}{c}{ Description } \\
\hline 1 & & Flow line & Shows the direction from one process to the next. \\
\hline 2 & & Terminal & Indicates the Beginning or End of a Process. \\
\hline 3 & & Process & State the activities that will occur in the flow chart. \\
\hline 4 & & Connecting & Connecting point at the same thing. \\
\hline
\end{tabular}




\section{Research Method}

This research was conducted at PPI Lhok Pawoh, Sawang District, South Aceh Region, Aceh Province. Within a period of 5 months starting from 1 March 2019 to 31 July 2019.

\section{A. Research Approach}

The flow chart of financial transactions carried out by market operators at the PPI Lhok Pawoh does not yet have sufficient initial data so that this study is included in basic research or preliminary research. Basic research is research intended for the development of a science and directed at developing existing theories or discovering new theories [12].

\section{B. Research Design}

According to Burn \& Grove the research design is a research blueprint for conducting a study with maximum control over factors that can influence the validity of an finding [13]. On the other hand Polit et al explain the research design as everything that researchers are able to do to answer the problem or try a research hypothesis, so it is necessary to arrange a research design [14]. This research is designed to answer how the financial transaction process and payment process between market operators is carried out. This will be answered by conducting a case study. This case study is conducted on market operators in PPI Lhok.

\section{Data Types and Source}

Type of data used in this study is in the form of primary data and secondary data. Secondary data is data that has been collected and analyzed by someone [15]. Whereas Primary data is obtained through direct observation and interviews with market operators using unstructured interview methods. The respondents who will be the source of the required primary data can be seen in table 2.

Tabel 2. List of respondents

\begin{tabular}{clc}
\hline No & \multicolumn{1}{c}{ Data Source } & Qtty \\
\hline 1 & Panglima Laut & 1 \\
\hline 2 & DKP South Aceh District & 1 \\
\hline 3 & Fisherman & 2 \\
\hline 4 & Toke Bangku & 3 \\
\hline 5 & Toke Ikan & 1 \\
\hline 6 & Muge Besar & 2 \\
\hline 7 & Muge Lapak & 2 \\
\hline 8 & Muge Motor & 2 \\
\hline 9 & Consumer & 2 \\
\hline Total & & 14 \\
\hline
\end{tabular}

\section{Data Analysis Method}

Qualitative analysis requires creativity with challenges how to put raw data into meaningful logic; test them as a whole; and find ways to communicate their interpretation to others [16]. Qualitative analysis is done descriptively which aims to find out deeply about the pattern of financial transactions in PPI Lhok Pawoh. So it can be concluded that the researcher or analyst plays an important role in this stage.

\section{Result and Discussion}

PPI Lhok Pawoh began operating in 2013, having 13 fishing boats with at least 500 workers accommodated in the PPI. Business activities at PPI Lhok Pawoh involve fishermen as fish producers and market operators as agents that simplify the marketing process. Fishermen are people who actively engage in fishing activities as a livelihood. While consumers are scattered in districts where PPI Lhok Pawoh is located, Sawang sub-district and neighboring sub-districts. Based on field observations, there are several types of market operators at Lhok pawoh fish landing center (PPI) as seen in Table 3. 
Tabel 3. Market Operator at PPI Lhok Pawoh

\begin{tabular}{cl}
\hline No & \multicolumn{1}{c}{ Market Operator } \\
\hline 1 & Toke Bangku \\
\hline 2 & Toke Ikan \\
\hline 3 & Muge \\
\hline
\end{tabular}

Toke bangku is a term for a person who is a fisherman representative in selling and providing information on the price of fish catches in the market. Toke ikan are individuals who collect fish through Toke bangku to be marketed outside the area or factory. Muge is a person whose job is as a buyer, distributor and seller of fish catches from fishermen. Based on field observations, there are several types of muge that operate in PPI Lhok Pawoh, which can be seen in table 4 .

Tabel 4. Types of Muge

\begin{tabular}{cl}
\hline No & \multicolumn{1}{c}{ Types of Muge } \\
\hline 1 & Muge Besar \\
\hline 2 & Muge Motor \\
\hline 3 & Muge Lapak \\
\hline
\end{tabular}

Muge besar is a person who buys large quantities of fish and then marketed to Muge lapak and consumers directly in traditional markets. Muge lapak is a person who buys fish directly at PPI or from Muge besar which is then marketed to consumers. Muge motor is a person who takes fish from manager and is then marketed to consumers.

Based on the above data, it can be concluded that there are five types of market operators in PPI Lhok Pawoh, namely: Toke bangku, Toke ikan, Muge besar, Muge lapak and Muge motor.

\section{A. Types of Finacial Transaction That Done by Market Operators}

PPI Lhok Pawoh is a large-scale fish producer PPI in Sawang District. So that many market operators involved in the process of marketing fish catches. Every muge that enters PPI Lhok Pawoh can directly buy fish to toke bangku without having to involve certain parties in the transaction process, as well as market operators to consumers.

At the Fish Landing Center (PPI), the transaction process begins with the fixing of the basic price carried out by toke bangku and customer, price approval and payment of fish. After the process is complete, the consumer marketing process begins. the transaction process carried out by market operators is carried out according to their respective agreements among market operators. Every financial transaction is carried out personally because the market operator does not constitute an integrated entity within an organization. Therefore, each of them conduct business activities independently. This reveals that every transaction carried out by market operators is included in external transactions. The payment methods that are often used by market operators in PPI Lhok Pawoh are divided into 2 types, namely: (1) Cash Payment, (2) Non-cash payments.

\section{B. Cash Payment}

This cash payment is often done by muge motor, muge lapak and consumers who buy fish directly from toke bangku with a minimum capacity of fifty kilo grams $(50 \mathrm{~kg})$. But not all muge motor make cash payments, one of the benches said that the ones who often make cash payments 
are those who come from outside the Lhok Pawoh village, for example from the districts of Meukek, Samadua and Tapaktuan. Of the many muges motor that take fish at PPI Lhok Pawoh, only $25 \%$ make cash payments when collecting fish at the PPI.

Meanwhile, consumers who buy fish from muge motor or muge lapak, they make direct payments in cash. This was obtained from an interview with one of the consumers, saying that when buying fish at a muge lapak or muge motor always make cash payments directly. The proof of payment used by market operators in the PPI Lhok Pawoh uses receipts, which is a proof of transactions regarding receipt of money for payment of one item. Receipts are made and signed by both parties, both those who receive money and those who have made payments. Usually the receipt consists of two parts, namely the first and second parts. From the above statement it can be concluded that those making the cash payment process can be seen in Table 5.

Tabel 5. Transaction that done by Cash payment

\begin{tabular}{cccc}
\hline \multirow{2}{*}{ No } & \multicolumn{2}{c}{ Financial Transaction } & Qtty (\%) \\
\cline { 2 - 3 } & From & To & \\
\hline 1 & Consumer & Toke Bangku & $100 \%$ \\
\hline 2 & Consumer & Muge Lapak & $100 \%$ \\
\hline 3 & Consumer & Muge Besar & $100 \%$ \\
\hline 3 & Consumer & Muge Motor & $100 \%$ \\
\hline 4 & Muge Motor & Toke Bangku & $25 \%$ \\
\hline 5 & Muge Lapak & Muge Besar & $100 \%$ \\
\hline 6 & Muge Lapak & Toke Bangku & $100 \%$
\end{tabular}

\section{Non-cash payments}

Non-cash payment here is not a payment using a credit card but a payment made after fish taken from Toke bangku are sold to consumers. From the results of interviews with the Toke bangku, Rusman, said that almost every market operator makes non-cash payments, they make payments after fish taken from Toke bangku are sold. Even payment is made the next day or payment is made when taking the next fish. Non-cash payments involves toke ikan, muge besar, muge motor and toke bangku to fishermen. The payment process from toke bangku to fishermen is paid the next day when the fish managed by toke bangku are sold out. Non-cash payments can be seen in Table 6 .

Tabel 6. Transaction that done by non-cash payment

\begin{tabular}{cllc}
\hline \multirow{2}{*}{ No } & \multicolumn{2}{c}{ Financial Transaction } & Qtty (\%) \\
\cline { 2 - 3 } & \multicolumn{1}{c}{ From } & \multicolumn{1}{c}{ To } & \\
\hline 1 & Toke Bangku & Fisherman & $100 \%$ \\
\hline 2 & Toke Ikan & Toke Bangku & $100 \%$ \\
\hline 3 & Muge Besar & Toke Bangku & $100 \%$ \\
\hline 4 & Muge Motor & Toke Bangku & $75 \%$ \\
\hline
\end{tabular}


D. Flow Chart of Financial Transaction Carried by Market Operators in PPI Lhok Pawoh.

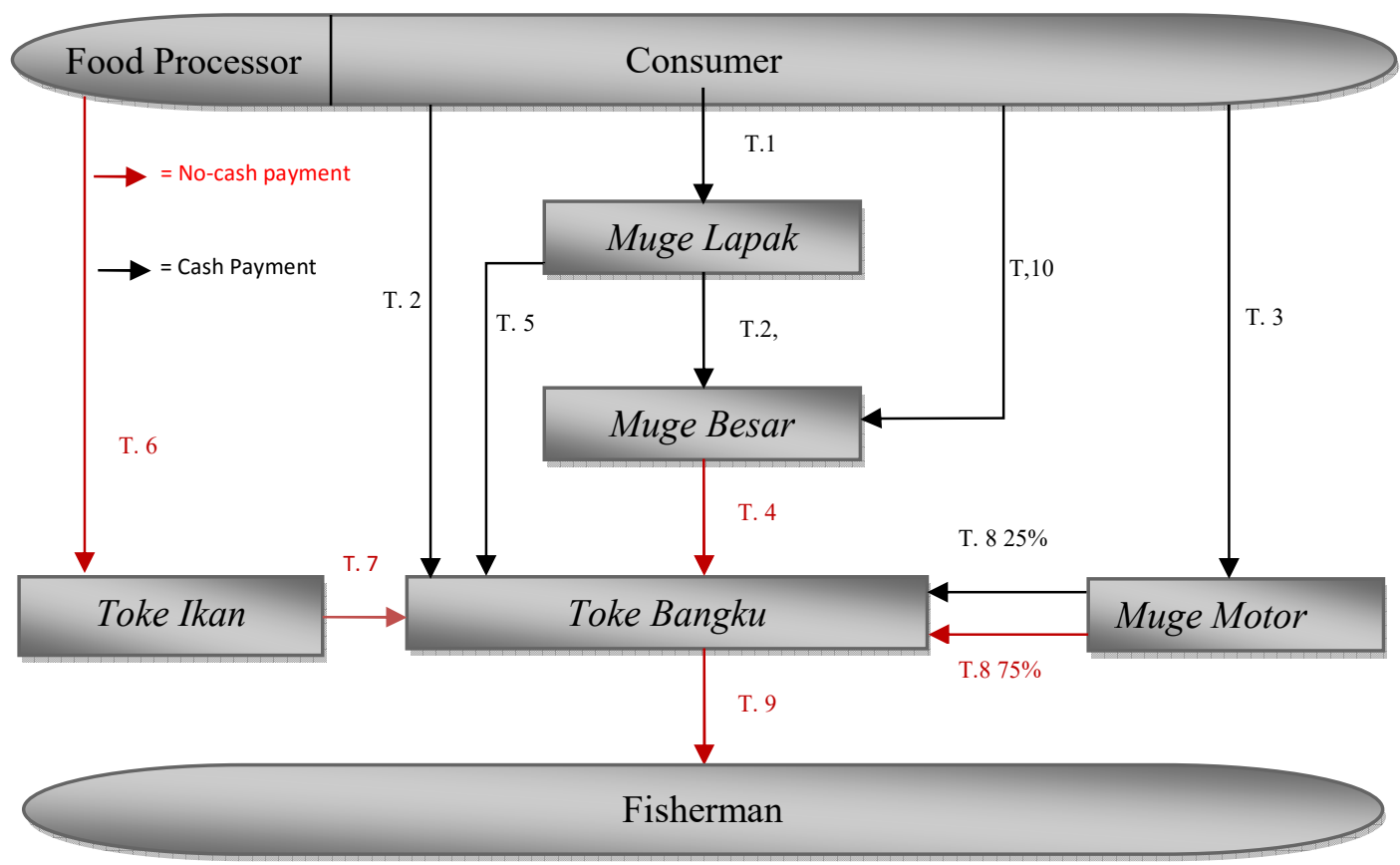

Figure 1. Flow Chart of financial transaction carried by market operator at PPI Lhok Pawoh.

Where :

T.1. Transactions conducted by consumers to muge lapak is using cash payment methods.

T.2. Transactions conducted by consumers to toke bangku is using cash payment methods.

T.3. Transactions conducted by consumers to Muge Motor is using the cash payment method.

T.4. Muge besar makes transactions to toke bangku by using the cash payment method.

T.5. Muge lapak carries transactions to toke bangku by using cash payment methods.

T.6. Food processor conduct transactions to toke ikan using non-cash payment methods

T.7. Toke ikan makes transactions to toke bangku by using non-cash payment methods.

T.8. Muge Motor makes transactions to toke Bangku by using a $75 \%$ non-payment method.

T.8. Muge motor makes transactions to toke bangku by using a $25 \%$ cash payment method.

T.9. Payments made by toke bangku to fishermen is using non-cash payment methods.

T.10Consumers make transactions to muge besar by using cash payment method.

\section{Conclusion}

The research revealed that PPI Lhok Pawoh is run by 5 types of market operators, namely: Toke bangku, Toke ikan, Muge besar, Muge lapak and Muge motor. All financial transactions used by market operators in PPI Lhok Pawoh are included in external transactions, because they are not under the same organization and running their business personally. Most of financial transaction process carried out by market operators at PPI Lhok Pawoh is using the non-cash payment method, except for muge motor which originating from outside of Lhok Pawoh Village, muge lapak and consumers who buy fish directly to PPI. In addition, It is found also that only $25 \%$ of muge motor make cash payments and the rest carried non-cash payment.

\section{ACKNOWLEDGMENT}

The study was supported by Ministry of Research, Technology and Higher Education of the Republic of Indonesia, DKP South Aceh District, fisherman and market operator in PPI Lhok Pawoh. We thank our colleagues from South Aceh Polytechnic who provided insight and expertise that greatly assisted the research. 


\section{DAFTAR PUSTAKA}

[1] Muchlisin, Z.A., Nazir, Muhammad, Musman Musri. 2012. Pemetaan Potensi Daerah Untuk Pengembangan Kawasan Minapolitan Di Beberapa Lokasi Dalam Provinsi Aceh:Suatu Kajian Awal, hlm.68-77 Jurnal Depik Universitas syiah Kuala.

[2] LKKP. 2015. Grafik Produksi ikan Meningkat. Laporan Kementerian Kelautan dan perikanan.

[3] DKP Aceh Selatan. 2014. "Produksi Perikanan Aceh Selatan 40\% Diekspor", http://www.medanbisnisdaily.com/, diakses pada Rabu, 18 Mar 2015 07:15 Wib.

[4] Heyne. 2014. Pasar Merupakan Tempat Terjadinya Pertukaran Barang dan Jasa, Jurnal Manajemen Bisnis Dan Kewirausahaan, hlm,192.

[5] Stanton W.J. 1994. dalam N, L, Ambar. Perkembangan Konseb Pemasaran Implementasi Dan Implikasinya, Jurnal Ekonomi Dan Kewirausahaan Vol 14, No 1,hlm 17.

[6] Kotler.P \& G, Amstrong, 2006. Prinsib-Prinsib Pemasaran, Edisi XII, Jilid 2, Erlanngga, Jakarta.

[7] Effendi dan Oktariza. 2006. Managemen Agribisnis Perikanan. Penebar Swadaya. Jakarta.

[8] ESMA. 2016. Market Operator (MIFID) Market Operators and data Reporting services providers.

[9] Mardi. 2011. Pengertian Transaksi, Jurnal Keuangan Pentingnya Transaksi Dalam Pencatatan Keuangan.

[10] Rafika, A.S. \& Situmorung, Romanda. 2017. Jurnal Sistem Pembayaran, Vol 3, No 1.

[11] Santoso, J. 2000. Monografi Kecamatan Geneng Kabupaten Ngawi.

[12] Dharma,S. 2008. Pendekatan, Jenis, dan Metode Penelitian Pendidikan. Jakarta: Dirjen PMPTK.

[13] Burns, N \& Grove, SK. 2003, Understanding Nursing Recearch, 3th. ed, Philadelphia : WB Saunders Company.

[14] Polit et al. 2001. Nursing research: Principles and methods. Philadelphia: Lippincot.

[15] Kothari, C. R. 2004. Research Methodology: Methods and Techniques. New Delhi: New Age International (P) Ltd.,Publishers.

[16] Simon C. et. Al. 2011 "Quality in qualitative research. 